\title{
ANALISIS TREN DAN PERBANDINGAN CAR, NPF, PEMENUHAN PPAP, ROA, BOPO, CASH RATIO DAN FDR PADA BANK SYARIAH MANDIRI DAN BANK MUAMALAT PERIODE DESEMBER 2004 SAMPAI DENGAN DESEMBER 2013'1
}

\author{
Archelia Imarvianti \\ Mahasiswa Program Studi S1 Ekonomi Islam-Fakultas Ekonomi dan Bisnis-Universitas Airlangga \\ Email: chely_archeli@ymail.com \\ Dina Fitrisia Septiarini \\ Departemen Ekonomi Syariah-Fakultas Ekonomi dan Bisnis-Universitas Airlangga \\ Email: dina.fitrisia@gmail.com
}

\begin{abstract}
:
This research is to know the trend and the differences of financial performance between Bank Syariah Mandiri and Bank Muamalat in the periods of 2004-2013. This research used quantitative for the research method, purposive sampling for the sampling technique, Bank Syariah Mandiri and Bank Muamalat for the sample. This research conduct the trend analyzed, and conduct the comparative analyzed with independent sample t-test. This research used seven variables to evaluate the financial performance which was CAR, NPF, the fulfillment of PPAP, ROA, BOPO, cash ratio, and FDR.

The trend analysis showed that Bank Syariah Mandiri has better progress on CAR, BOPO, cash ratio, and FDR, whereas Bank Muamalat has better progress on NPF, the fulfillment of PPAP and ROA. The comparative analysis showed that there are no differences on BOPO and cash ratio, whereas there are differences on CAR, NPF, the fulfillment of PPAP, ROA, and FDR.
\end{abstract}

Keywords: Trend analysis, comparative analysis, financial performance, Bank Syariah Mandiri, Bank Muamalat.

\section{PENDAHULUAN}

\section{Latar Belakang}

Mit Ghamr Bank di Mesir adalah bank syariah pertama yang beroperasi pada tahun 1960-an, dan Islamic Development Bank pada tahun 1970-an (Antonio, 2001:19). Di Indonesia, Bank Muamalat Indonesia menjadi bank syariah pertama yang mulai beroperasi pada 1 Mei 1992, kemudian diikuti dengan pendirian Bank Syariah Mandiri pada tahun 1999. Setelah kehadiran dua bank dengan sistem syariah tersebut perkembangan dunia perbankan syariah di Indonesia semakin membaik.

Bank syariah harus dapat meningkatkan kinerja keuangan yang dimilikinya. Hal ini dikarenakan, saat suatu bank syariah memiliki kinerja keuangan yang semakin baik, maka sistem operasional yang dimilikinya akan semakin baik juga, sehingga akan semakin tinggi pula pendapatan dan juga bagi hasil yang mampu diberikan bank syariah kepada nasabah. Kusumo (2008) juga menyatakan bahwa dengan kinerja keuangan yang baik, maka suatu bank akan dapat lebih bersaing dalam memperebutkan pasar perbankan nasional di Indonesia.

Sesuai dengan Peraturan Bank Indonesia Nomor: 9/1/PBI/2007 tentang Sistem Penilaian Tingkat Kesehatan Bank Umum Berdasarkan Prinsip Syariah Pasal 3, penilaian kesehatan dari suatu bank dapat dilakukan dengan metode CAMEL. Sholihin 
(2010:195) menyatakan bahwa CAMEL merupakan tolak ukur objek pemeriksaan bank yang dilakukan oleh pengawas bank. CAMEL terdiri atas lima aspek, yaitu modal (capital), aktiva (aset), manajemen (management), pendapatan (earnings), dan likuiditas (liquidity). Namun karena dalam penelitian ini hanya menganalisis tentang kinerja keuangan, maka aspek manajemen (management) tidak dianalisis. Hal ini, dikarenakan aspek tersebut bukan merupakan bagian dari aspek keuangan dalam suatu bank (Kusumo: 2008).

Penilaian kinerja keuangan bank dapat dipergunakan untuk membuktikan kepada masyarakat bahwa bank syariah tersebut dapat dipercaya karena dalam keadaan baik sehingga dapat beroperasi serta melayani masyarakat dengan baik. Selain itu, juga dapat digunakan sebagai penilaian kinerja manajemen apakah sudah memenuhi target yang telah ditetapkan atau belum, kemudian juga dapat menilai kemampuan manajemen dalam memberdayakan sumber daya perusahaan apakah sudah efektif atau belum (Kasmir, 2013:104-105). Penilaian dari masing-masing rasionya dapat digunakan sebagai upaya identifikasi permasalahan lebih dini agar dapat melakukan perbaikan dengan lebih tepat dan cepat, sehingga bank tersebut dapat menetapkan strategi usaha di masa yang akan datang dengan lebih tepat.

\section{Rumusan Masalah}

1. Bagaimana tren kinerja kevangan Bank Syariah Mandiri dan Bank Muamalat periode 2004-2013 dari segi CAR, NPF, pemenuhan PPAP, ROA, BOPO, cash ratio, dan FDR?

2. Apakah terdapat perbedaan kinerja keuangan Bank Syariah Mandiri dan Bank Muamalat periode 2004-2013 dari segi CAR, NPF, pemenuhan PPAP, ROA, BOPO, cash ratio, dan FDR?

\section{Tujuan Penelitian}

1. Mengetahui tren kinerja keuangan Bank Syariah Mandiri dan Bank Muamalat periode 2004-2013 dari segi CAR, NPF, pemenuhan PPAP, ROA, BOPO, cash ratio, dan FDR.

2. Mengetahui perbedaan kinerja keuangan Bank Syariah Mandiri dan Bank Muamalat periode 2004-2013 dari segi CAR, NPF, pemenuhan PPAP, ROA, BOPO, cash ratio, dan FDR.

\section{LANDASAN TEORI DAN PENGEMBANGAN HIPOTESIS}

\section{Pengertian Laporan Keuangan}

Menurut Kasmir (2013:7) laporan kevangan adalah laporan yang menunjukkan kondisi keuangan perusahaan pada saat ini atau dalam suatu periode tertentu.

\section{Analisis Laporan Keuangan}

Subramanyan dan Wild (2010:4) menyatakan bahwa analisis laporan keuangan (financial statement analysis) adalah aplikasi dari alat dan teknik analisis laporan keuangan bertujuan umum dan data-data yang berkaitan untuk 
menghasilkan estimasi dan kesimpulan yang bermanfaat dalam analisis bisnis.

\section{Analisis Tren}

Subramanyan dan Wild (2010: 34) menyatakan bahwa analisis tren dilakukan dengan cara menelaah neraca, laporan laba rugi, atau laporan arus kas yang berurutan dari satu periode ke periode berikutnya. Data yang lebih dari tiga periode dianalisis dengan menggunakan angka indeks. Rumus dari angka Indeks adalah (Kasmir, 2013: 82-84).

$$
\text { Angka Indeks }=\frac{\text { Tahun Pembanding }}{\text { Tahun Dasar }} \times 100 \%
$$

\section{Kinerja Kevangan Bank Syariah Capital (Permodalan)}

Berdasarkan Peraturan Bank Indonesia Nomor 9/1/PBI/2007 Tentang Sistem Penilaian Tingkat Kesehatan Bank Umum Berdasarkan Prinsip Syariah pasal 4 menyatakan bahwa Penilaian terhadap faktor permodalan didasarkan pada komponen kecukupan, proyeksi permodalan dan kemampuan permodalan dalam mengcover risiko. Komponen ini dapat diartikan sebagai rasio yang mengukur modal terhadap Aktiva Tertimbang Menurut Risiko (ATMR) atau Capital Adequacy Ratio (CAR).

\section{Asset Quality (Kualitas Aktiva Produktif)}

Berdasarkan Surat Edaran Bank Indonesia No. 9/24/DPbS 2007 Tentang Sistem Penilaian Tingkat Kesehatan Bank Umum Berdasarkan Prinsip Syariah Romawi II.2 menyatakan bahwa penilaian kualitas aset merupakan penilaian terhadap kondisi aset Bank atau Unit Usaha Syariah (UUS) dan kecukupan manajemen risisko pembiayaan.

Penilaian terhadap kualitas aktiva produktif di dalam ketentuan Bank Indonesia didasarkan pada 2 rasio, yaitu:

1. Rasio Non Performing Financing (NPF) untuk mengukur risiko terhadap pembiayaan yang disalurkan dengan membandingkan pembiayaan macet dengan jumlah pembiayaan yang disalurkan (Rafelia dan Ardiyanto, 2013).

2. Rasio Pemenuhan Penyisihan Penghapusan Aktiva Produktif (PPAP) adalah cadangan yang dibentuk dengan membebani laba rugi tahun berjalan untuk menampung kerugian yang mungkin timbul disebabkan oleh tidak kembalinya sebagian atau seluruh aktiva produktif (Sholihin, 2010:640).

\section{Management (Manajemen)}

Berdasarkan Surat Edaran Bank Indonesia No. 9/24/DPbS 2007 Tentang Sistem Penilaian Tingkat Kesehatan Bank Umum Berdasarkan Prinsip Syariah Romawi II.6 menyatakan bahwa penilaian manajemen merupakan penilaian terhadap kemampuan manajerial pengurus bank untuk menjalankan usaha, kecukupan manajemen risiko, dan kepatuhan bank terhadap ketentuan yang berlaku serta komitmen kepada Bank Indonesia atau pihak lainnya.

\section{Earnings (Rentabilitas)}


Berdasarkan Surat Edaran Bank Indonesia No. 9/24/DPbS 2007 Tentang Sistem Penilaian Tingkat Kesehatan Bank Umum Berdasarkan Prinsip Syariah Romawi II.3 menyatakan bahwa penilaian rentabilitas merupakan penilaian terhadap kondisi dan kemampuan Bank dan Unit Usaha Syariah (UUS) untuk menghasilkan keuntungan dalam rangka mendukung kegiatan operasional dan permodalan.

Penilaian aspek rentabilitas didasarkan pada 2 rasio, yaitu:

1. Rasio Return on Assets (ROA) untuk mengukur kemampuan perusahaan dalam memperoleh earning dalam operasi perusahaan (Suryani, 2011).

2. Rasio Beban Operasional Pendapatan Operasional (BOPO) untuk mengetahui kemampuan bank syariah dalam menutupi biaya operasional dengan pendapatan operasionalnya.

\section{Liquidity (Likuiditas)}

Berdasarkan Surat Edaran Bank Indonesia No. 9/24/DPbS 2007 Tentang Sistem Penilaian Tingkat Kesehatan Bank Umum Berdasarkan Prinsip Syariah Romawi II.4 menyatakan bahwa penilaian likuiditas merupakan penilaian terhadap kemampuan bank untuk memelihara tingkat likuiditas yang memadai.

Penilaian aspek likuiditas didasarkan pada 2 rasio, yaitu:

1. Cash ratio digunakan untuk mengukur seberapa besar uang kas yang tersedia untuk membayar hutang.
2. Suryani (2011) menyatakan bahwa rasio Financing to Deposit Ratio (FDR) digunakan untuk mengukur likuiditas bank dalam membayar kembali penarikan dana yang dilakukan oleh deposan dengan pembiayaan sebagai sumber likuiditasnya.

\section{Hipotesis}

$\mathrm{H}_{1}$ : Terdapat perbedaan kinerja keuangan antara Bank Syariah Mandiri dan Bank Muamalat dengan menggunakan rasio Capital Adequancy Ratio (CAR) periode 2004-2013.

$\mathrm{H}_{2}$ : Terdapat perbedaan kinerja keuangan antara Bank Syariah Mandiri dan Bank Muamalat dengan menggunakan rasio Non Performing Financing (NPF) periode 2004-2013.

$\mathrm{H}_{3}$ : Terdapat perbedaan kinerja keuangan antara Bank Syariah Mandiri dan Bank Muamalat dengan menggunakan rasio Pemenuhan Penyisihan Penghapusan Aktiva Produktif (PPAP) periode 2004-2013.

$\mathrm{H}_{4}$ : Terdapat perbedaan kinerja keuangan antara Bank Syariah Mandiri dan Bank Muamalat dengan menggunakan rasio Return on Asset (ROA) periode 2004-2013.

$\mathrm{H}_{5}$ : Terdapat perbedaan kinerja kevangan antara Bank Syariah Mandiri dan Bank Muamalat dengan menggunakan rasio, Biaya Operasional Pendapatan Operasional (BOPO) periode 20042013.

$\mathrm{H}_{6}$ : Terdapat perbedaan kinerja keuangan Bank Syariah Mandiri dan Bank 
Muamalat dengan menggunakan rasio Cash Ratio periode 2004-2013.

$\mathrm{H}_{7}$ : Terdapat perbedaan kinerja keuangan Bank Syariah Mandiri dan Bank Muamalat dengan menggunakan rasio Financing Deposit Ratio (FDR) periode 2004-2013.

\section{METODOLOGI PENELITIAN}

\section{Pendekatan Penelitian}

Pendekatan dalam penelitian ini adalah pendekatan kuantitatif. Teknik analisis yang digunakan adalah statistik deskriptif. Setelah itu, peneliti melakukan analisis tren dan analisis perbandingan dengan menggunakan alat uji statistik t-Test dan SPSS sebagai alat statistik.

\section{Identifikasi Variabel}

Variabel yang digunakan dalam penelitian ini adalah sebagai berikut:

1. Capital Adequacy Ratio (CAR)

2. Non Performing Financing (NPF)

3. Pemenuhan Penyisihan Penghapusan Aktiva Produktif (PPAP)

4. Return on Assets (ROA)

5. Biaya Operasional Pendapatan Operasional (BOPO)

6. Cash Ratio

7. Financing Deposit Ratio (FDR)

\section{Definisi Operasional Variabel}

1. Capital Adequacy Ratio (CAR) untuk mengetahui kemampuan bank syariah dalam menjaga kecukupan modal. CAR didapat dari rumus sebagai berikut (Dendawijaya, 2005:144):

$C A R=\frac{\text { Modal }}{\text { Alktiva Tertimbang Menurut Risiko(ATMR) }} \times 100 \%$
Data ini merupakan data rasio dan diambil secara tahunan dari tahun 2004-2013.

2. Non Performing Financing (NPF) untuk mengukur risiko terhadap pembiayaan yang disalurkan dengan membandingkan pembiayaan macet dengan jumlah pembiayaan yang disalurkan. NPF didapat dari rumus sebagai berikut:

NPF $=\frac{\text { Jumlah Pembiayaan Bermasalah }}{\text { Total Pemblayaan }} \times 100 \%$

Data ini merupakan data rasio dan diambil secara tahunan dari tahun 2004-2013.

3. Pemenuhan Penyisihan Penghapusan Aktiva Produktif (PPAP) untuk mengetahui kemampuan bank syariah dalam menentukan besarnya PPAP yang telah dibentuk terhadap PPAP yang wajib dibentuk. Pemenuhan PPAP didapat dari rumus sebagai berikut (Budisantoso dan Triandaru 2006:58):

Pemenuhan $F F A F=\frac{\text { PFAP yang telah di bentulk }}{\text { PPAP yang Wajib dibentuk }} \times 100 \%$

Data ini merupakan data rasio dan diambil secara tahunan dari tahun 2004-2013.

4. Return on Assets (ROA) untuk mengukur kemampuan bank syariah dalam memperoleh keuntungan (laba sebelum pajak) yang diperoleh dari total aset yang dimiliki oleh bank tersebut. ROA didapat dari rumus sebagai berikut (Dendawijaya, 2005:146):

ROA $=\frac{\text { Laba Sebelum Pajak }}{\text { Total Aktiva }} \times 100 \%$ 
Data ini merupakan data rasio dan diambil secara tahunan dari tahun 2004-2013.

5. Biaya Operasional Pendapatan Operasional (BOPO) untuk mengukur kemampuan bank syariah dalam membayar beban operasional dari dengan menggunakan pendapatan operasional yang telah dimiliki oleh bank syariah tersebut. BOPO didapat dari rumus sebagai berikut (Dendawijaya, 2005:147):

BOPO $=\frac{\text { Beban Operasional }}{\text { Pend apatan Operasional }} \times 100 \%$

Data ini merupakan data rasio dan diambil secara tahunan dari tahun 2004-2013.

6. Cash Ratio untuk mengukur kemampuan bank syariah dalam membayar kewajiban jangka pendek dengan menggunakan alat likuid yang terdiri dari kas dan aktiva antar bank yang dimiliki oleh bank tersebut. Cash ratio didapat dari rumus sebagai berikut (Kasmir, 2013:139):

Cash Ratio $=\frac{\text { Kas }+ \text { Bank }}{\text { Kewajiban Lancar }}$

Data ini merupakan data rasio dan diambil secara tahunan dari tahun 2004-2013.

7. Financing Deposit Ratio (FDR) untuk mengukur kemampuan bank syariah dalam memenuhi pembiayaan dengan menggunakan Dana Pihak Ketiga (DPK) dan juga modal yang dimiliki oleh bank syariah tersebut. FDR didapat dari rumus sebagai berikut (Suryani, 2011):
FDR $=\frac{\text { Jumlah Dana Yang Diberkan }}{\text { Total Dana Pihak Ketiga (DPK) }} \times 100 \%$

Data ini merupakan data rasio dan diambil secara tahunan dari tahun 2004-2013.

\section{Jenis dan Sumber Data}

Jenis data dalam penelitian ini adalah data sekunder berupa laporan keuangan dari Bank Syariah Mandiri dan Bank Muamalat periode 2004-2013. Data yang dipergunakan adalah data time series, yang diperoleh dari website Bank Indonesia (www.bi.go.id), website Bank Syariah Mandiri (www.syariahmandiri.co.id), dan Bank Muamalat (www.bankmuamalat.co.id).

\section{Populasi dan Sampel}

Populasi yang digunakan dalam penelitian ini adalah sejak Bank Syariah Mandiri dan Bank Muamalat berdiri sampai dengan tahun 2013.

Teknik pengambilan sampel yang digunakan adalah purposive sampling. Beberapa pertimbangan yang diambil adalah sampel yang diambil adalah selama periode 2004-2013. Pengambilan periode diawali pada tahun 2004 dikarenakan peneliti akan melakukan penelitian dalam jangka waktu 10 tahun terakhir, dan diakhiri pada tahun 2013 dikarenakan laporan kevangan per 31 Desember 2014 belum dipublikasikan secara resmi.

\section{Teknik Analisis}

Langkah-langkah untuk menganalisis masalah yang telah dirumuskan diawali dengan menghitung rasio kinerja kevangan, kemudian dikelompokkan 
berdasarkan tahun masing-masing. Tahap berikutnya adalah melakukan penghitungan angka indeks yang dilanjutkan dengan analisis tren, dan penggambaran tren dari kedua Bank Umum Syariah tersebut selama 10 tahun. Setelah itu dilakukan uji normalitas (Kolmogrov-smirnov). Data akan berdistribusi normal saat nilai sig $>0,05$, sedangkan saat nilai sig $<0,05$ maka data berdistribusi tidak normal.

Tahap berikutnya adalah uji beda yaitu uji † untuk dua sampel independent/bebas (Independent sample t-test). Uji ini diawali dengan menentukan $\dagger$ hitung menggunakan equal variances assumed saat nilai sig $F$ hitung $>0,05$ atau equal variance not assumed saat nilai sig $\mathrm{F}$ hitung $<0,05$. Setelah itu, akan dilakukan pengambilan keputusan dari $\dagger$ hitung. Ho akan diterima saat nilai sig $\dagger>$ dari 0,05, sedangkan Ho akan ditolak saat nilai sig $\dagger<$ dari 0,05.

\section{HASIL DAN PEMBAHASAN}

\section{Deskripsi Hasil Penelitian}

1. Deskripsi Hasil Penelitian Bank Syariah Mandiri

Tabel 1.

Analisis Statistik Deskriptif Rasio Kinerja Kevangan (CAR, NPF, Pemenuhan PPAP) ** Bank Syariah Mandiri dan Bank Muamalat (Dalam Persentase)

\begin{tabular}{|c|c|c|c|}
\hline & CAR & NPF & P. PPAP \\
\hline Mean & 12,56 & 3,86 & 106,93 \\
\hline Maks & 14,57 & 6,38 & 127,64 \\
\hline Min & 10,57 & 2,22 & 100 \\
\hline
\end{tabular}

Sumber: Hasil Penelitian, 2015 (diolah)

Pada tabel 1 dapat diketahui bahwa nilai rata-rata CAR Bank Syariah Mandiri adalah $12,56 \%$ dengan nilai tertinggi $14,57 \%$ dan nilai terendah $10,57 \%$. Nilai rata-rata NPF adalah $3,86 \%$ dengan nilai tertinggi $6,38 \%$ dan nilai terendah $2,22 \%$. Nilai rata-rata pemenuhan PPAP adalah $106,93 \%$ dengan nilai tertinggi $127,64 \%$ dan nilai terendah $100 \%$.

Tabel 2.

Analisis Statistik Deskriptif Rasio Kinerja Keuangan (ROA, BOPO, cash ratio, FDR)** Bank Syariah Mandiri dan Bank Muamalat (Dalam Persentase)

\begin{tabular}{|c|c|c|c|c|}
\hline & ROA & BOPO & CR & FDR \\
\hline Mean & 1,93 & 79,13 & 1,01 & 88,33 \\
\hline Maks & 2,86 & 85,70 & 1,34 & 94,40 \\
\hline Min & 1,10 & 73,00 & 0,63 & 82,54 \\
\hline
\end{tabular}

Sumber: Hasil Penelitian, 2015 (diolah)

Pada tabel 2 dapat diketahui bahwa nilai rata-rata $\mathrm{ROA}$ adalah $1,93 \%$ dengan nilai tertinggi $2,86 \%$ dan nilai terendah $1,1 \%$. Nilai rata-rata BOPO adalah $79,13 \%$ dengan nilai tertinggi $85,7 \%$ dan nilai terendah $73 \%$. Nilai rata-rata cash ratio adalah $1,01 \%$ dengan nilai tertinggi 1,34\% dan nilai terendah $0,63 \%$. Nilai rata-rata FDR adalah $88,33 \%$ dengan nilai tertinggi $94,4 \%$ dan nilai terendah $82,54 \%$.

\section{Deskripsi Hasil Penelitian Bank Muamalat}

Tabel 3.

Analisis Statistik Deskriptif Rasio Kinerja Keuangan (CAR, NPF, Pemenuhan PPAP) Bank Syariah Mandiri dan Bank Muamalat (Dalam Persentase)

\begin{tabular}{|c|c|c|c|}
\hline & CAR & NPF & P. PPAP \\
\hline Mean & 12,95 & 2,82 & 108,12 \\
\hline Maks & 17,27 & 4,96 & 126,52 \\
\hline Min & 10,69 & 1,07 & 100 \\
\hline
\end{tabular}

Sumber: Hasil Penelitian, 2015 (diolah)

Pada tabel 3 dapat diketahui bahwa nilai rata-rata CAR Bank Muamalat adalah 
$12,95 \%$ dengan nilai tertinggi $17,27 \%$ dan nilai terendah $10,69 \%$. Nilai rata-rata NPF adalah 2,82\% dengan nilai tertinggi 4,96\% dan nilai terendah $1,07 \%$. Nilai rata-rata pemenuhan PPAP adalah 108,12\% dengan nilai tertinggi $126,52 \%$ dan nilai terendah $100 \%$.

\section{Tabel 4.}

Analisis Statistik Deskriptif Rasio Kinerja Keuangan (ROA, BOPO, cash ratio, FDR) Bank Syariah Mandiri dan Bank Muamalat (Dalam Persentase)

\begin{tabular}{|c|c|c|c|c|}
\hline & ROA & BOPO & CR & FDR \\
\hline Mean & 1,75 & 85,27 & 1,42 & 91,89 \\
\hline Maks & 2,60 & 95,50 & 2,29 & 104,41 \\
\hline Min & 0,45 & 78,94 & 0,87 & 83,6 \\
\hline
\end{tabular}

Sumber: Hasil Penelitian, 2015 (diolah)

Pada tabel 4 dapat diketahui bahwa nilai rata-rata $\mathrm{ROA}$ adalah $1,75 \%$ dengan nilai tertinggi $2,6 \%$ dan nilai terendah $0,45 \%$. Nilai rata-rata BOPO adalah $85,27 \%$ dengan nilai tertinggi $95,5 \%$ dan nilai terendah $78,94 \%$. Nilai rata-rata cash ratio adalah 1,42\% dengan nilai tertinggi 2,29\% dan nilai terendah $0,87 \%$. Nilai rata-rata FDR adalah $91,89 \%$ dengan nilai tertinggi $104,41 \%$ dan nilai terendah $83 \%$.

\section{Analisis Tren}

1. Analisis Tren Capital Adequancy Ratio (CAR)

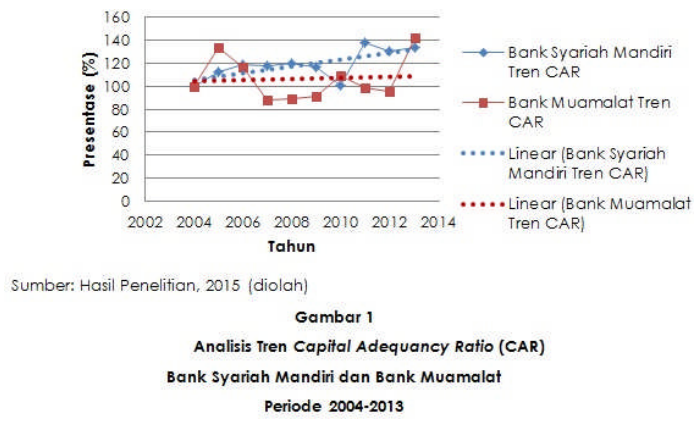

Dari grafik diatas dapat diketahui bahwa perkembangan Bank Syariah
Mandiri dari segi CAR lebih baik. Hal ini dikarenakan garis linier yang dimiliki oleh Bank Syariah Mandiri lebih meningkat jika dibandingkan dengan garis linier yang dimiliki oleh Bank Muamalat.

\section{Analisis Tren Non Performing Financing (NPF)}

Dari grafik dibawah dapat diketahui bahwa perkembangan Bank Muamalat dari segi NPF lebih baik. Hal ini dikarenakan garis linier yang dimiliki oleh Bank berada dibawah garis linier yang dimiliki oleh Bank Syariah Mandiri.

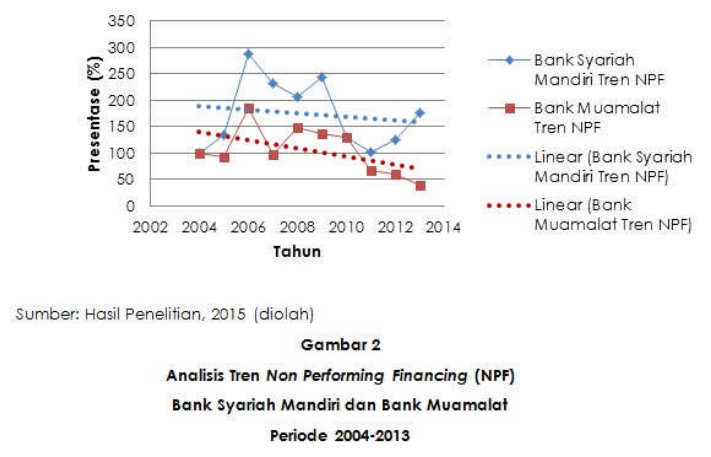

3. Analisis Tren Pemenuhan Penyisihan Penghapusan Aktiva Produktif (PPAP)

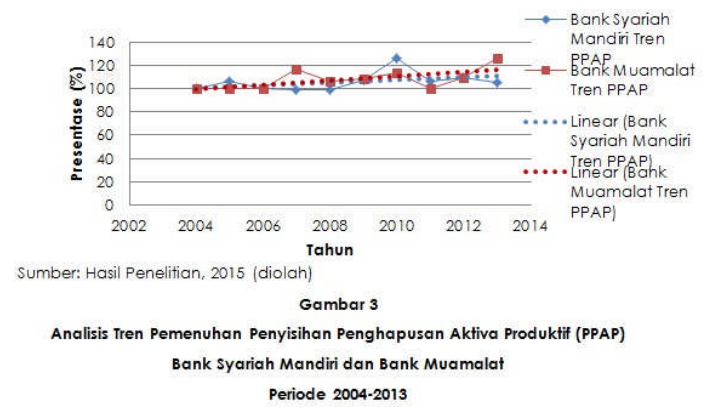

Dari grafik diatas dapat diketahui bahwa perkembangan Bank Muamalat dari segi pemenuhan PPAP lebih. Hal ini dikarenakan garis linier yang dimiliki oleh Bank Muamalat lebih meningkat jika dibandingkan dengan garis linier yang dimiliki oleh Bank Syariah Mandiri.

\section{Analisis Tren Return on Assets (ROA)}


Dari grafik dibawah dapat diketahui bahwa perkembangan Bank Muamalat dari segi ROA lebih baik. Hal ini dikarenakan garis linier yang dimiliki oleh Bank Muamalat yang berada diatas garis linier yang dimiliki oleh Bank Syariah

Mandiri.

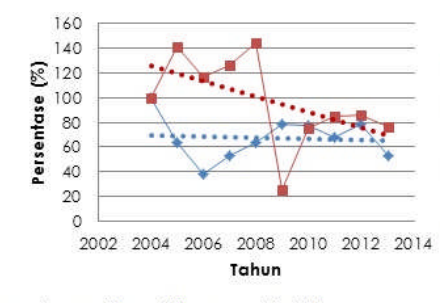

Bank Syariah Mandiri Tren ROA

- Bank Muamalat Tren $R O A$

- Linear (Bank Syariah Mandiri Tren ROA)

- Linear (Bank

Sumber: Hasil Penelitian, 2015 (diolah)

Gambar 4

Analisis Tren Return on Assets (ROA)

Bank Syariah Mandiri dan Bank Muamalat

Periode 2004-2013

5. Analisis Tren Beban Operasional Pendapatan Operasional (BOPO)

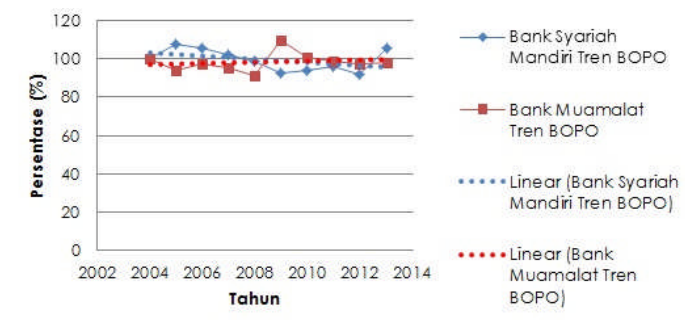

Sumber: Hasil Penelitian, 2015 (diolah)

Gambar 5

Analisis Tren Beban Operasional Pendapatan Operasional (BOPO) Bank Syariah Mandiri dan Bank Muamalat Periode 2004-2013

Dari grafik diatas dapat diketahui bahwa perkembangan Bank Syariah Mandiri dari segi BOPO lebih baik. Hal ini dikarenakan garis linier yang dimiliki oleh Bank Syariah Mandiri lebih menurun jika dibandingkan dengan garis linier yang dimiliki oleh Bank Muamalat.

\section{Analisis Tren Cash Ratio}

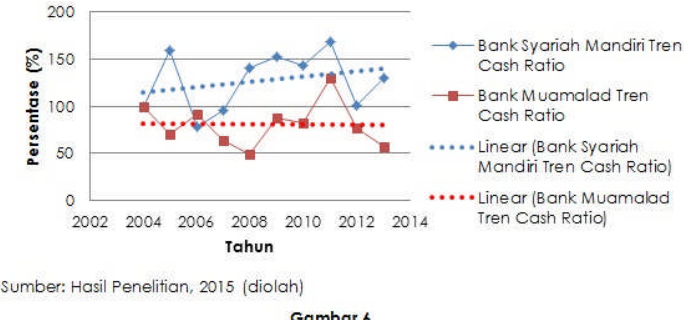

Gambar 6

Analisis Tren Cash Ratio

Bank Syariah Mandiri dan Bank Muamalat

Periode 2004-2013

Dari grafik diatas dapat diketahui bahwa perkembangan Bank Syariah Mandiri dari segi cash ratio lebih baik. Hal ini dikarenakan garis linier yang dimiliki oleh Bank Syariah Mandiri lebih berada diatas garis linier yang dimiliki oleh Bank Syariah Mandiri.

\section{Analisis Tren Financing Deposit Ratio (FDR)}

Dari grafik dibawah dapat diketahui bahwa perkembangan Bank Syariah Mandiri dari segi FDR lebih baik. Hal ini dikarenakan garis linier yang dimiliki oleh Bank Syariah Mandiri berada dibawah garis linier yang dimiliki oleh Bank Muamalat.

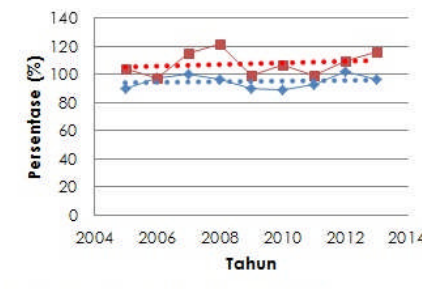

- Bank Syariah Mandir Tren FDR 100

- Bank Muamalat Tren FDR 100

..... Linear (Bank Syariah Mandiri Tren FDR 100 - Linear Bank Muamalat Tren FDR

Sumber: Hasil Penelitian, 2015 (diolah)

Gambar 7

Analisis Tren Financing Deposit Ratio (FDR) Bank Syariah Mandiri dan Bank Muamalat Periode 2004-2013

\section{Analisis Model dan Pengujian Hipotesis}

Tabel 5.

Uji Normalitas Data Semua Variabel

\begin{tabular}{|c|c|c|c|}
\hline Variabel & $\mathbf{N}$ & Sig. & Keterangan \\
\hline CAR & 20 & 0,611 & Normal \\
\hline NPF & 20 & 0,779 & Normal \\
\hline PPAP & 20 & 0,511 & Normal \\
\hline
\end{tabular}




\begin{tabular}{|c|c|c|c|}
\hline ROA & 20 & 0,984 & Normal \\
\hline BOPO & 20 & 0,934 & Normal \\
\hline Cash ratio & 20 & 0,917 & Normal \\
\hline FDR & 20 & 0,776 & Normal \\
\hline
\end{tabular}

Sumber: Hasil Penelitian, 2015 (diolah)

Pada tabel 5 dapat diketahui bahwa semua variabel dinyatakan normal karena memiliki nilai signifikansi yang berada diatas 0,05.

\section{Uji Beda}

Semua variabel dalam penelitian ini memiliki data berdistribusi normal, maka pengujian menggunakan uji † untuk dua sampel independent/bebas (Independent sample t-test).

Tabel 6. Independent sample t-test Semua Variabel

\begin{tabular}{|c|c|c|c|c|c|}
\hline \multirow{2}{*}{ Var. } & & \multicolumn{2}{|c|}{ Levene's Test } & \multirow{2}{*}{ Sig. } & \multirow{2}{*}{ Ket. } \\
\hline & & $\mathbf{F}$ & Sig. & & \\
\hline \multirow[b]{2}{*}{ CAR } & $\begin{array}{c}\text { Equal } \\
\text { variances } \\
\text { assumed }\end{array}$ & 3,421 & 0,081 & 0,653 & $\begin{array}{l}\text { Ho diterima } \\
\text { (Tidak ada } \\
\text { perbedaan) }\end{array}$ \\
\hline & $\begin{array}{c}\text { Equal } \\
\text { variance } \\
\text { not } \\
\text { assumed }\end{array}$ & & & 0,654 & \\
\hline \multirow[b]{2}{*}{ NPF } & $\begin{array}{c}\text { Equal } \\
\text { variances } \\
\text { assumed }\end{array}$ & 0,955 & 0,341 & 0,097 & $\begin{array}{l}\text { Ho diterima } \\
\text { (Tidak ada } \\
\text { perbedaan) }\end{array}$ \\
\hline & $\begin{array}{c}\text { Equal } \\
\text { variance } \\
\text { not } \\
\text { assumed }\end{array}$ & & & 0,098 & \\
\hline \multirow[b]{2}{*}{ PPAP } & $\begin{array}{c}\text { Equal } \\
\text { variances } \\
\text { assumed }\end{array}$ & 0,459 & 0,507 & 0,761 & $\begin{array}{l}\text { Ho diterima } \\
\text { (Tidak ada } \\
\text { perbedaan) }\end{array}$ \\
\hline & $\begin{array}{c}\text { Equal } \\
\text { variance } \\
\text { not } \\
\text { assumed }\end{array}$ & & & 0,761 & \\
\hline $\mathrm{ROA}$ & $\begin{array}{c}\text { Equal } \\
\text { variances } \\
\text { assumed }\end{array}$ & 0,832 & 0,374 & 0,498 & $\begin{array}{l}\text { Ho diterima } \\
\text { (Tidak ada } \\
\text { perbedaan) }\end{array}$ \\
\hline
\end{tabular}


Mandiri dan Bank Muamalat pada sisi BOPO, dan cash ratio.

\section{Pembahasan}

\section{Pembahasan Analisis Tren}

1. Capital Adequancy Ratio (CAR)

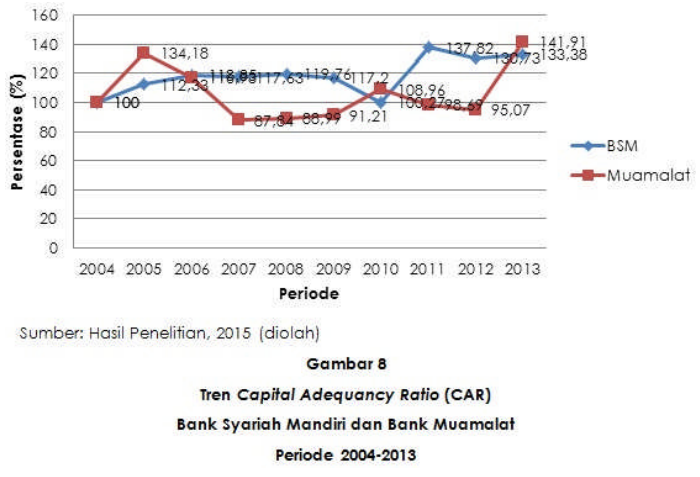

Dari grafik 8 dapat diketahui bahwa perkembangan rasio Capital Adequancy Ratio (CAR) dari Bank Muamalat pada tahun 2006 mengalami penurunan yang cukup besar sampai berada dibawah perkembangan rasio CAR dari Bank Syariah Mandiri. Hal ini dikarenakan peningkatan Aktiva Tertimbang Menurut Risiko (ATMR) dari Bank Muamalat yang lebih tinggi daripada modal, sehingga modal yang dimiliki oleh Bank Muamalat kurang mampu untuk mengcover risiko dari aktiva yang dimiliki oleh bank syariah tersebut.

Pada grafik 8 juga dapat diketahui bahwa pada tahun 2010 sampai dengan tahun 2012, perkembangan rasio CAR Bank Muamalat kembali mengalami penurunan yang cukup besar sementara Bank Syariah Mandiri dapat meningkatkan nilai rasio ini dengan cukup baik dan stabil sampai dengan tahun 2013.

\section{Non Performing Financing (NPF)}

Dari grafik 9 dapat diketahui bahwa pada tahun 2010, perkembangan dari rasio Non Performing Financing (NPF) yang dimiliki oleh Bank Syariah Mandiri mengalami peningkatan yang cukup besar sampai hampir menyamai perkembangan rasio NPF yang dimiliki oleh Bank Muamalat. Hal ini menunjukkan bahwa persentase pembiayaan dalam golongan macet yang dimiliki oleh Bank Syariah Mandiri mengalami penurunan dengan cukup baik.

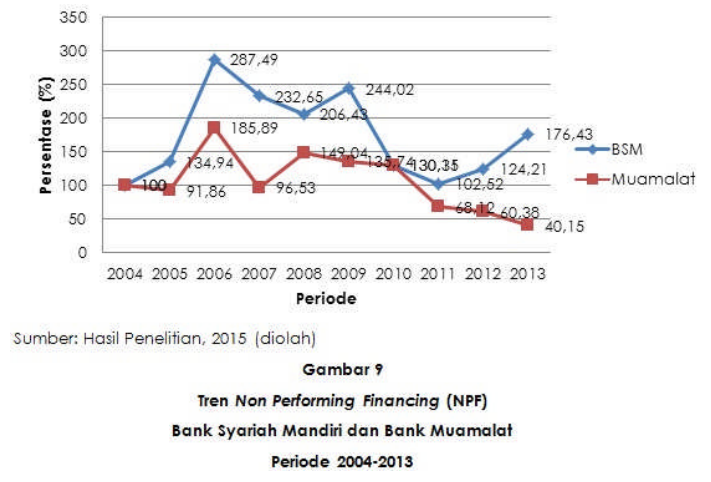

3. Pemenuhan Penyisihan Penghapusan Aktiva Produktif (PPAP)

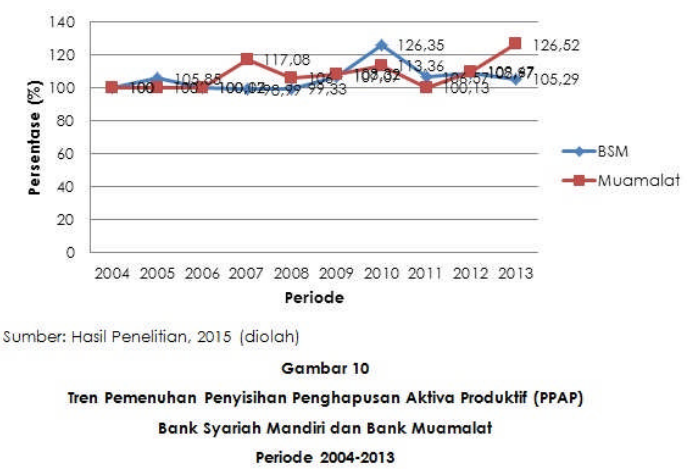

Dari grafik diatas dapat diketahui bahwa perkembangan rasio pemenuhan Penyisihan Penghapusan Aktiva Produktif (PPAP) Bank Bank Syariah Mandiri pada tahun 2005 mengalami peningkatan daripada Bank Muamalat. Hal ini menunjukkan bahwa Bank Syariah Mandiri dapat membentuk Penyisihan Penghapusan Aktiva Produktif (PPAP) yang lebih tinggi daripada yang seharusnya 
dibentuk sehingga Bank Syariah Mandiri dapat mengcover risiko dengan lebih baik, meskipun tingginya PPAP dapat mengurangi keuntungan yang diperoleh.

Dari grafik 10 dapat diketahui bahwa pada tahun 2009, Bank Syariah Mandiri mengalami peningkatan sampai hampir menyamai perkembangan nilai dari rasio pemenuhan PPAP dari Bank Muamalat. Pada tahun 2012, bank Muamalat kembali mengalami peningkatan perkembangan pada rasio ini sampai dengan tahun 2013, sedangkan Bank Syariah Mandiri kembali mengalami penurunan sampai dengan tahun 2013.

\section{Return on Assets (ROA)}

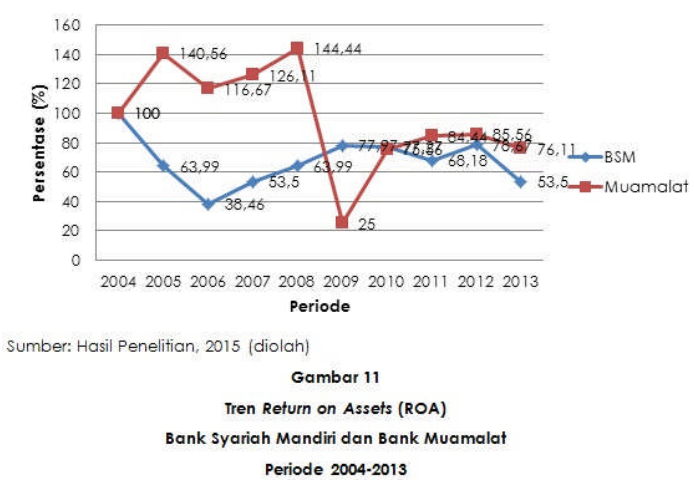

Dari grafik diatas dapat diketahui bahwa pada tahun 2009, Bank Muamalat mengalami mengalami penurunan perkembangan rasio Return on Assets (ROA) yang cukup jauh yaitu sebesar $75 \%$. Hal ini dikarenakan peningkatan total aset yang dimiliki oleh Bank Muamalat tidak diikuti dengan peningkatan laba rugi sebelum pajak yang membuktikan bahwa Bank Muamalat kurang mampu mengelola aset yang dimilikinya padahal total aset yang dimilikinya mengalami peningkatan.

\section{Beban Operasional Pendapatan Operasional (BOPO)}

Dari grafik 12 dapat diketahui bahwa kedudukan Bank Muamalat yang sebelumnya berada diatas Bank Syariah Mandiri ternyata pada tahun 2009 sampai dengan tahun 2012 berada dibawah Bank Syariah Mandiri. Hal ini dikarenakan peningkatan beban operasional dari Bank Muamalat yang sebelumnya dapat dikategorikan cukup rendah. Namun pada tahun 2013 kedudukan Bank Muamalat kembali berada diatas Bank Syariah Mandiri.

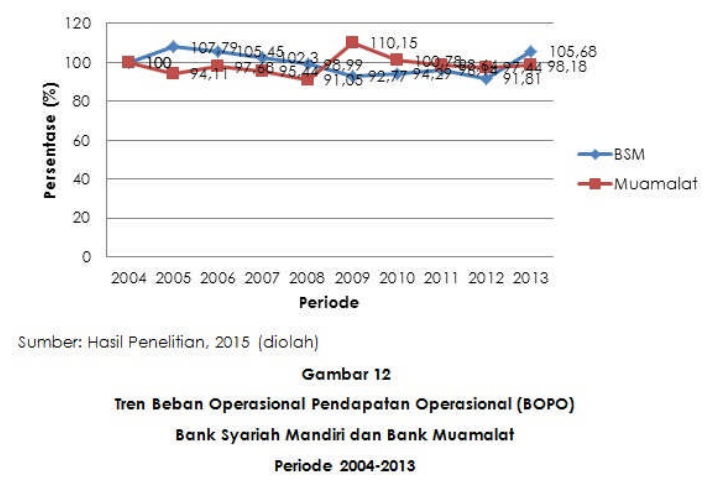

6. Cash Ratio.

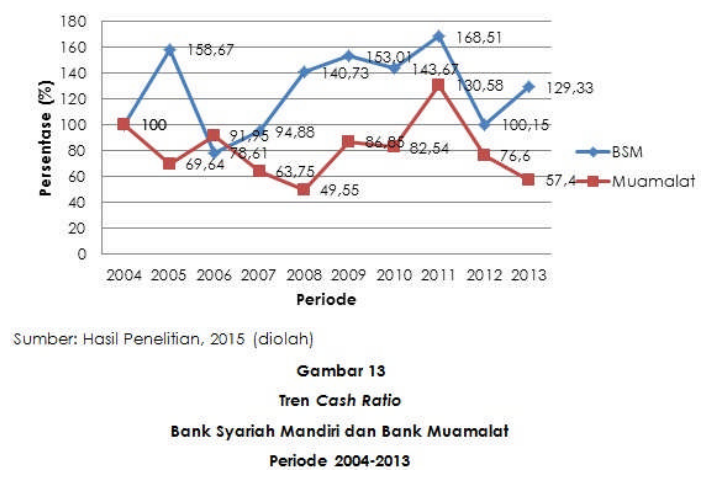

Dari grafik diatas dapat diketahui bahwa pada tahun 2006 perkembangan cash ratio dari Bank Muamalat mengalami peningkatan yang cukup baik daripada Bank Syariah Mandiri. Penurunan yang dialami oleh Bank Syariah Mandiri disebabkan oleh minimnya alat likuid yang dimilikinya sehingga tidak mencukupi tingginya kewajiban lancar yang dimiliki, 
sedangkan Bank Muamalat berhasil meningkatkan alat likuid yang dimilikinya. Namun pada tahun-tahun berikutnya Bank Syariah Mandiri berhasil kembali memperbaiki perkembangan nilai dari rasio ini.

\section{Financing Deposit Ratio (FDR).}

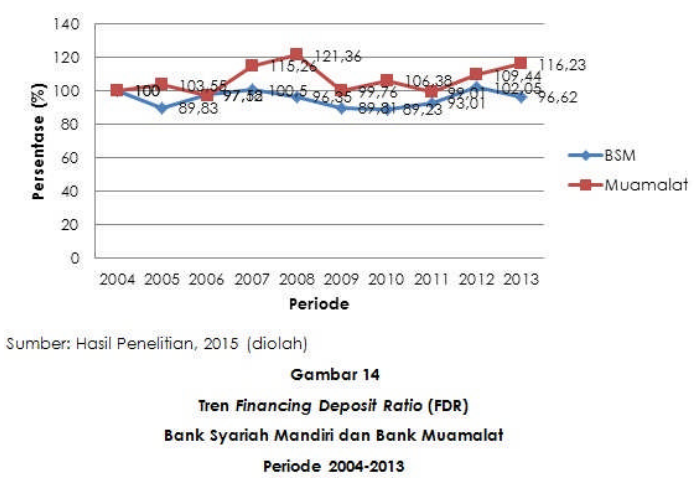

Dari grafik 14 dapat diketahui bahwa pada tahun 2006, perkembangan rasio Financing Deposit Ratio (FDR) yang dimiliki oleh kedua Bank Umum Syariah tersebut berada diangka yang hampir sama. Hal ini dikarenakan jumlah Dana Pihak Ketiga (DPK) yang telah dihimpun oleh kedua Bank Umum Syariah tersebut telah mampu menyalurkan dana tersebut dalam bentuk beberapa pembiayaan dengan persentase penyaluran yang hampir sama.

\section{Pembahasan Uji Beda}

\section{Capital Adequacy Ratio (CAR)}

Berdasarkan uji yang telah dilakukan, dapat dinyatakan bahwa tidak terdapat perbedaan kinerja kevangan dari segi rasio CAR diantara keduanya. Penelitian ini mendukung penelitian yang dilakukan oleh Fatih (2014) dan Dahlia (2012) yang menunjukkan bahwa tidak terdapat perbedaan diantara kedua Bank Umum Syariah tersebut dari segi rasio CAR.
Hal tersebut disebabkan oleh ketetapan dari Bank Indonesia mengenai nilai minimum dari rasio ini yaitu sebesar $8 \%$, sehingga setiap bank syariah berlombalomba untuk dapat memenuhi standar tersebut agar dapat dinyatakan sehat dalam segi modal.

\section{Non Performing Financing (NPF)}

Berdasarkan uji yang telah dilakukan, dapat dinyatakan bahwa dari kedua Bank Umum Syariah tersebut ternyata tidak terdapat perbedaan kinerja kevangan dari segi rasio NPF diantara keduanya. Hal ini dikarenakan Bank Indonesia telah menetapkan standar dari rasio ini yaitu dibawah 5\% untuk dapat dinyatakan sehat. Ketetapan tersebut adalah salah satu cara untuk melindungi pihak bank dari risiko-risiko kerugian yang mungkin muncul karena kualitas aktiva produktif yang kurang baik atau bahkan macet.

Aktiva produktif yang macet tidak hanya berdampak pada nasabah yang mendapatkan pembiayaan tersebut tetapi juga berdampak pada terancamnya kelangsungan hidup bank tersebut lebih lanjut (Kasmir, 2013: 285). Oleh sebab itu, perlu dilakukan pemberlakuan prinsip 5C (character, capacity, capital, condition, collateral) kepada nasabah sebelum memberikan pembiayaan sebagai salah satu upaya untuk meminimalisir kemungkinan risiko dari aktiva produktif dalam keadaan macet. 


\section{Pemenuhan Penyisihan Penghapusan Aktiva Produktif (PPAP)}

Berdasarkan uji yang telah dilakukan, dapat dinyatakan bahwa dari kedua Bank Umum Syariah tersebut ternyata tidak terdapat perbedaan kinerja keuangan dari segi rasio pemenuhan PPAP diantara keduanya. Hal tersebut dikarenakan Bank Indonesia telah menetapkan standar untuk rasio yaitu diatas $81 \%$, sehingga bank-bank tersebut akan berusaha untuk dapat memenuhi standar tersebut agar dapat dinyatakan sehat.

Selain dari sisi rasio pemenuhan PPAP, perhitungan cadangan yang harus dilakukan dari masing-masing kategori atau yang dapat disebut dengan PPAP yang wajib dibentuk yang menjadi tolak ukur dari rasio ini juga telah ditetapkan oleh Bank Indonesia yaitu 0\% untuk kategori aktiva produktif lancar, 5\% untuk kategori aktiva produktif dalam perhatian khusus, $15 \%$ untuk kategori aktiva produktif kurang lancar, 50\% untuk kategori aktiva produktif diragukan, dan $100 \%$ untuk kategori aktiva produktif macet (Leon dan Ericson, 2007: 108).

\section{Return on Assets (ROA)}

Berdasarkan uji yang telah dilakukan, dapat dinyatakan bahwa tidak terdapat perbedaan kinerja kevangan dari segi rasio ROA diantara keduanya. Penelitian ini mendukung penelitian yang dilakukan oleh Fatih (2014) dan Dahlia (2012) yang menunjukkan bahwa tidak terdapat perbedaan diantara kedua Bank Umum Syariah tersebut dari segi rasio ROA.

Hal tersebut disebabkan oleh standar maksimal yang ditetapkan oleh Bank Indonesia, sehingga setiap bank syariah berlomba-lomba untuk dapat melebihi batas minimum yaitu sebesar $1,215 \%$ agar dapat dinyatakan sehat. Selain itu, semakin meningkatnya rasio ini juga menandakan bahwa bank syariah tersebut telah mampu untuk meningkatkan keuntungan yang diperolehnya diluar sektor operasional yaitu dari pengelolaan total aset yang dimilikinya sehingga pendapatan bank syariah dapat bertambah.

\section{Biaya Operasional Pendapatan Operasional (BOPO)}

Berdasarkan uji yang telah dilakukan, dapat dinyatakan bahwa terdapat perbedaan kinerja keuangan dari segi rasio BOPO diantara keduanya. Penelitian ini mendukung penelitian yang dilakukan oleh Fatih (2014) dan Dahlia (2012) yang menunjukkan bahwa terdapat perbedaan diantara kedua Bank Umum Syariah tersebut dari segi rasio BOPO.

Hal tersebut disebabkan oleh tingkat efisiensi tiap bank syariah yang berbeda. Setiap bank syariah memiliki ketentuan sendiri tentang besar kecilnya masingmasing beban operasional yang dimilikinya, seperti patokan beban gaji, biaya promosi, biaya administrasi, dan sebagainya yang berbeda setiap bank syariah yang biasanya disesuaikan dengan 
kebijakan dari masing-masing bank syariah.

\section{Cash Ratio}

Berdasarkan uji yang telah dilakukan, dapat dinyatakan bahwa terdapat perbedaan kinerja kevangan dari segi cash ratio diantara keduanya. Hal ini dikarenakan terdapat dua motif adanya permintaan uang dalam Islam yaitu motif transaksi dan motif berjaga-jaga yang ditentukan oleh tingkat pendapatan uang dan distribusinya (Chapra, 2000: 134).

Setiap bank syariah memiliki alasan tersendiri dalam hal pengelolaan alat likuidnya, terdapat beberapa bank syariah yang lebih memilih mempertahankan alat likuidnya dalam jumlah yang besar dengan motif berjagajaga agar dapat memudahkan nasabah yang ingin mengambil dananya dengan berbagai alasan. Namun terdapat beberapa bank syariah yang lebih memilih untuk tetap menyediakan alat likuidnya tetapi tidak dalam jumlah yang besar agar alat likuid tersebut dapat dikelola kembali.

\section{Financing Deposit Ratio (FDR)}

Berdasarkan uji yang telah dilakukan, dapat dinyatakan bahwa tidak terdapat perbedaan kinerja kevangan dari segi rasio FDR diantara keduanya. Penelitian ini bertentangan penelitian yang dilakukan oleh Fatih (2014) dan Dahlia (2012) yang menunjukkan bahwa terdapat perbedaan diantara kedua Bank Umum Syariah tersebut dari segi rasio FDR.
Hal tersebut disebabkan oleh standar maksimal yang ditetapkan oleh Bank Indonesia, sehingga setiap bank akan berusaha untuk dapat memenuhi ketentuan tersebut yaitu berada dibawah standar maksimal yaitu sebesar 93,5\% agar dapat memiliki penilaian tingkat kesehatan yang sehat.

\section{v. SIMPULAN}

Simpulan dari tren kinerja keuangan Bank Syariah Mandiri dan Bank Muamalat pada periode 2004-2013 adalah:

1. Perkembangan pada rasio CAR, BOPO, cash ratio, dan FDR yang dimiliki oleh Bank Syariah Mandiri lebih baik.

2. Perkembangan pada rasio NPF, pemenuhan PPAP dan ROA yang dimiliki oleh Bank Muamalat lebih baik. Simpulan dari uji beda kinerja keuangan Bank Syariah Mandiri dan Bank Muamalat periode 2004-2013 adalah:

1. Berdasarkan uji beda $(a=0,05)$ pada periode 2004-2013 pada rasio BOPO dan cash ratio terdapat perbedaan kinerja keuangan.

2. Berdasarkan uji beda $(a=0,05)$ pada periode 2004-2013 pada pada rasio CAR, NPF, pemenuhan PPAP, ROA dan FDR tidak terdapat perbedaan kinerja kevangan.

Saran yang direkomendasikan adalah:

1. Bagi Bank Syariah Mandiri diharapkan dapat lebih meningkatkan pemberlakuan prinsip 5C (character, capacity, capital, condition, collateral) sebelum memberikan pembiayaan, meningkatkan pengelolaan aset yang 
sebenarnya cukup tinggi dan meningkatkan alat likuid yang dimilikinya.

2. Bagi Bank Muamalat diharapkan dapat meningkatkan alat likuid yang dimilikinya dan mengatur pembiayaan yang akan dilakukan.

3. Bagi peneliti yang akan datang diharapkan dapat menggunakan lebih banyak rasio untuk mengukur kinerja keuangan dari bank syariah tersebut, dan diharapkan peneliti yang akan datang juga dapat memperbanyak sampel yang digunakan sehingga akan dapat lebih tergeneralisasi.

\section{DAFTAR PUSTAKA}

Antonio, Muhammad Syafi'i. 2001. Bank Syariah: Dari Teori Ke Praktik. Jakarta: Gema Insani Press.

Budisantoso, Totok \& Sigit Triandaru. 2006. Bank dan Lembaga Keuangan Lain, edisi kedua. Jakarta: Salemba Empat.

Chapra, M. Umer. 2000. Sistem Moneter Islam. Jakarta: Gema Insani Press.

Dahlia, Andi. 2012. Analisis Perbandingan Kinerja Kevangan PT. Bank Syariah Mandiri dengan PT. Bank Muamalat Indonesia. Skripsi tidak diterbitkan. Makassar Fakultas Ekonomi dan Bisnis Universitas Hasanuddin Makassar.

Dendawijaya, Lukman. 2005. Manajemen Perbankan, edisi kedua. Jakarta: Ghalia Indonesia.

Fatih, Muhammad Nur. 2014. Perbandingan Kinerja Keuangan PT
Bank Syariah Mandiri dengan PT Bank Muamalat Indonesia. Skripsi tidak diterbitkan. Tulungagung Fakultas Ekonomi dan Bisnis Islam Institut Agama Islam Negeri (IAIN) Tulungagung.

Kasmir. 2013. Analisis Laporan Kevangan. Jakarta: Rajawali Pers.

Kusumo, Yunanto Adi. 2008. Analisis Kinerja Keuangan Bank Syariah Mandiri Periode 2002-2007 (Dengan Pendekatan PBI No.9/1/PBI/2007) dalam Jurnal Ekonomi Islam La_Riba, (online), Vol. 2 No.1, (http://dtx.yolasite.com, diakses 30 Januari 2015).

Leon, Boy \& Sony Ericson. 2007. Manajemen Aktiva Pasiva Bank Non Devisa. Jakarta: PT Grafindo.

Republik Indonesia. Peraturan Bank Indonesia Nomor 9/1/PBI/2007 Tentang Sistem Penilaian Tingkat Kesehatan Bank Umum Berdasarkan Prinsip Syariah. Jakarta: Bank Indonesia.

Surat Edaran Bank

Indonesia No. 9/24/DPbS 2007 Tentang Sistem Penilaian Tingkat Kesehatan Bank Umum Berdasarkan Prinsip Syariah. Jakarta: Bank Indonesia.

Sholihin, Ahmad Irfam. 2010. Buku Pintar Ekonomi Syariah. Jakarta: PT Gramedia Pustaka Utama.

Subramanyan, \& John J. Wild. 2010. Analisis Laporan Keuangan buku 1. Jakarta: Salemba Empat.

Sujarweni, V Wiratna. 2014. SPSS Untuk Penelitian. Yogyakarta: Pustaka Baru Press. 
JESTT Vol. 2 No. 9 September 2015

Suryani. 2011. Analisis Pengaruh Financing

to Deposit Ratio (FDR) Terhadap

Profitabilitas Perbankan Syariah di

Indonesia dalam Jurnal Walisongo,

(online), Vol. 19, No.1,

(http://journal.walisongo.ac.id, diakses

27 Januari 2015).

www.bi.go.id

www.bankmuamalat.co.id

wwW.syariahmandiri.co.id 